\title{
A PRELIMINARY INVENTORY OF WEEVIL ASSEMBLAGES (COLEOPTERA, CURCULIONOIDEA) IN KHARKIV METROPOLITAN AREA (UKRAINE) USING PITFALL TRAPS
}

\author{
V. Yu. Nazarenko ${ }^{1}$, A. V. Putchkov ${ }^{1}$, N. A. Komaromi ${ }^{2}$ \\ ${ }^{1}$ Schmalhausen Institute of Zoology NAS of Ukraine \\ vul.B. Khmelnytskogo, 15, Kyiv, 01030 Ukraine \\ E-mail:nazarenko@izan.kiev.ua; putchkov@izan.kiev.ua \\ ${ }^{2}$ H. S. Skovoroda Kharkiv National Pedagogical University \\ Alchevskyh st., 29, Kharkiv, 61000 Ukraine \\ E-mail: nkomaromigHYPERLINK“mailto:nkomaromig@gmail.com”@HYPERLINK“mailto:nkomaromig@gmail. \\ com”gmailHYPERLINK “mailto:nkomaromig@gmail.com”.com
}

V. Yu. Nazarenko (http://orcid 0000-0003-4245-5049)

A. V. Putchkov (http://orcid 0000-0002-0652-3211)

N. A. Komaromi (http://orcid 0000-0002-9888-0530)

\begin{abstract}
A Preliminary Inventory of Weevil Assemblages (Coleoptera, Curculionoidea) in Kharkiv Metropolitan Area (Ukraine) Using Pitfall Traps. Nazarenko, V. Yu., Putchkov, A. V., Komaromi, N. A. - Species composition, the ecological structure and the occurrence characteristics of weevils (Curculionoidea) in the stratobios of the main urban habitats of Kharkiv were studied. 59 species from 41 genera and three families were registered. Curculionoidea comprises $31.5 \%$ of the coleopterofauna of stratobios. Approximately 10 species are attributed to dominants (2-3 species are eudominants). 40 species are ranked as random and 9 species are rare in the stratobios. 4 species of Curculionoidea (Cyanapion columbinum, Curculio rubidus, Otiorhynchus albidus, Tropiphorus micans) are recorded for the first time in the Left bank foreststeppe zone of Ukraine. The values of the main indices of species diversity were low, which may indicate a significant oligodominance of Curculionoidea in all urban habitats. Most of species are herba- and dendrobionts (14-17), but almost all of them are registered as random (27) or rare (4) elements. 26 species associated with stratobios (among which most dominants elements are recorded). Species associated with meadows (21) and forests, or eurytopic species (14) are dominants in the samples; by trophic links - oligo(32) and polyphagous species (24) were prevailed. 45 species prefer mesophilic habitats. The number of eurytopic mesophilous polyphagous stratogeobionts were maximal. The largest number of species (25-33) were documented in vegetation of the outskirts and household plots of city compared to the city parks and plantings of the center (18-19), but minimumly (12) in forest. The spectrum of ecological groups was also minimal in a forest, but the maximum is in the plantings of periphery and household plots of the city. Faunistic similarity was slightly more than 0.20 , which may indicate specific and significant differences in the species composition of weevils in different urban habitats of Kharkiv.
\end{abstract}

K e y wo r d s: Coleoptera, Curculinoidea, fauna, ecological structure, similarity, urban habitats, Kharkiv, Ukraine. 
The study of the formation of the entomofauna of a megalopolis makes it possible to understand its role in the urban environments, as well as to conduct an environmental estimation of the processes occurring in urban habitats. The Coleoptera is the largest order among insects, within which weevils (Curculionoidea) are one of the largest groups. Unlike some other beetles (for example, Carabidae), an insignificant number of publications is devoted to the study of Curculionoidea in urban landscapes in Europe and information on them is fragmentary (Cmoluch, 1972; Cholewicka, 1981; Weidner, 1983; Klausnitzer, 1990; Molodova, 1990, 1991; Elechtner, Klinger, 1991; Franzen, 1992 a, b; Matusevich, Kostin, 1994; Chumakov, 1999; Meleshko, 2002; Aleksandrowicz, Krzętowski, 2004; Halinouski, 2005; Korotyaev et al., 2018, 2019). These works dealt with the ecological features of some species rather than a faunistics. Nevertheless, such studies made it possible to obtain occurrence data and preliminarily assess the assemblages of Curculionoidea in some urban areas.

The faunistic studies of urban habitats in Ukraine are basically focused on ground beetles (Carabidae) of some metropolitan areas e. g. Dnipro (Brygadyrenko and Kabar, 2002), Kyiv (Putchkov et al., 2003, 2016, 2017 b, 2019 ; Kirichenko, Danylkiv, 2011; Putchkov, 2018), Lviv (Rizun, Kharapov, 2001; Rizun, Diedus, 2016) and Kharkiv (Putchkov et al., 2016; Komaromi et al., 2018; Nikolenko, 2018). Meanwhile, other beetle families, e. g. scarabs, rove beetles and clown beetles, are poorly studied (Putchkov et al., 2017 a; Putchkov, Komaromi, 2018). There are also dramatically few special studies dealing with weevils (Nazarenko, Petrenko, 2007; Putchkov et al., 2016; Komaromi et al., 2018, 2019; Nazarenko et al., 2018). The data on Curculionoidea is significantly fragmented among those papers.

This study is aimed to understand a transformation of weevil assemblages under urbanization by analyzing ecological and taxonomic structure of weevil fauna in in Kharkiv Metropolitan Area.

\section{Material and methods}

The sampling was carried out in the main urban habitats: the plantings in the center and peripheral territory of city (outskirts), three city parks, mini-parks, lawns of the household plots, downtown and suburbs (Oleksiivka District), and in the Lisopark (large patch of remaining primary deciduous forest within Kharkiv Metropolitan Area) in 2016-2018. Their characteristics are recently published (Putchkov et al., 2016; Fedyay et al., 2018; Komaromi et al., 2018).

Each of plots about 1000 square meters was allocated. Only the plot of city center is approximately equal $300 \mathrm{~m}^{2}$. The pitfall traps (200 ml plastic cups filled with $10 \%$ acetic acid solution) were used according to generally accepted methods (Gilyarov, 1987). By 10-20 pitfall traps were set up for each plots. Traps re-charged each 10-15 days from late April to mid-October. Additionally, weevils were collected at the plots by sifting leaf litter. The abundance indices and the ratio of weevil species are calculated according to averaged data, mainly the number of specimens per 100 trap-days for the entire accounting season.

In total, about 3000 specimens of Curculionoidea were collected in the stratobios of urban habitats. Four groups (based on the size of the sample) were distinguished in terms of abundance: eudominants (more than $10 \%$ of the total number of species within the family); subdominants $(0.6-10 \%)$; rare $(0.2-0.6 \%)$ and single (random) - less than 0.2 ( $\leq 3$ specimen for the entire period of inventory). The first two groups are considered as abundant for one or another urban habitat.

Classification follows Palaearctic Curculionoidea Catalogues (Catalogue of Palaearctic Coleoptera, 2011, 2013; Alonso-Zarazaga et al., 2017). The taxa in the tables and the text are given in alphabetical order (table 1).

The term "stratobios" used by a modern interpretation, accepted in Europe. Representatives of stratobios are invertebrate species found in the upper layer, on the surface of the soil and in plant litter. However ecologists, zoologists and entomologists of former USSR countries often use its synonym - "herpetobios", successfully developed in the works of some well-known scientists (Arnoldi, Arnoldi, 1963; Yakhontov, 1964; Skufyin, 1968). The biogeographic term "left-bank of Forest Steppe" (FS) used here in direct translation from Russian refers to the forest-steppes zone on the eastern Ukraine delimited from the west by Dnipro.

Essential biodiversity features were described with a variety of indices (Lebedeva et al., 2004). Jacquard index was employed to compare the similarity of the species composition in sampling plots. Shannon index, Pielou index and Margalef index were used to evaluate species richness and diversity. The species abundance distribution was assessed using Berger-Parker index. All calculations were done using the PAST program (table 2).

The species are ranked by ecological groups of imago: habitat, vertical distribution, trophic links, hygropreference according to own observations and publications (Yakhontov, 1964; Nazarenko, Petrenko, 2007; Komaromi et al., 2018; Yunakov et al., 2018). Features of spatial distribution in landscapes in different urban habitats (transgradients, dispersed, equivalent elements) also given as additional characteristics (Müller, 1980; Klausnitzer, 1983, 1990). The representative analysis was used to identify differences in the spreading and distribution peculiarities of ecologically different species of beetles over the plots. All divisions are partly subjective (especially in habitat layers and hygropreference), but are given in accordance with the conditions and nature of a particular site, taking into account the peculiarities of the change of stations of the species in different geographic regions of Ukraine. 


\section{Research results and discussion}

Curculionoidea, noted in the stratobios of Kharkiv, are one of the dominant groups of all beetles. In total, 59 species from 41 genera and three families were registered (table 1). By taxonomic diversity, the weevils take the second place by species richness after ground beetles (Caraboidea) (about 90 species), being exceeding rove beetles (Staphylinoidea) (near 50 species) (Komaromi et al., 2018). In the family Curculionidae the highest species richness was observed ( 53 species out of 35 genera), while Anthribidae and Brentidae are represented by 2 and 4 species respectively. However, 10 species from the genera Baris, Bradybatus, Curculio, Dorytomus, Hexarthrum, Melicius and Orchestes (table 1) were omitted in the Catalogues of Palaearctic Coleoptera (Catalogue..., 2011, 2013; Alonso-Zarazaga et al., 2017). Information about the findings of these species in Ukraine is available in a number of publications (Krynicki, 1832; Belke, 1858, 1859, 1866; Nowicki, 1858, 1864; Łomnicki, 1874; 1884; Hormuzaki, 1888; Cherkunov, 1889; Folwaczny, 1973; Nazarenko, Petrenko, 2007). This is taken into account and given in the recent survey of Curculionoidea of Ukraine (Yunakov et al., 2018). However, one species from the Brentidae (Cyanapion columbinum) and three Curculionidae (Curculio rubidus, Tropiphorus micans and invasive Otiorhynchus albidus wide spreading in urban areas) were registered as new for the forest-steppe zone (table 1). For eight species (Aulacobaris lepidii, Bradybatus kellneri, Dorytomus schoenherri, Hexarthrum

Table 1. The taxonomic structure, ecological and quantitative characteristics of the weevils (Curculinoidea) of stratobios in the main urban areas of Kharkiv City

\begin{tabular}{|c|c|c|c|c|c|c|c|c|}
\hline \multirow[b]{2}{*}{ Families, genera, species } & \multicolumn{3}{|c|}{$\begin{array}{l}\text { Ecological and quantitative } \\
\text { characteristics }\end{array}$} & \multicolumn{5}{|c|}{$\begin{array}{l}\text { Occurrence in urban areas } \\
\text { (in points) }\end{array}$} \\
\hline & 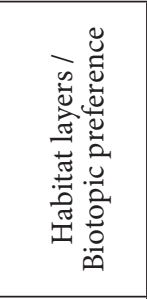 & 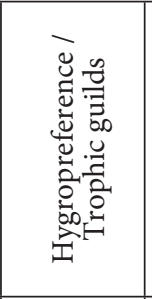 & 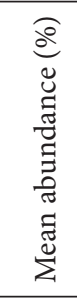 & 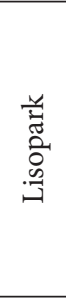 & 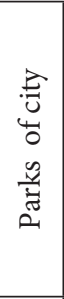 & 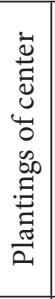 & 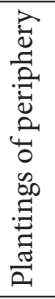 & 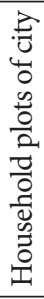 \\
\hline 1 & 2 & 3 & 4 & 5 & 6 & 7 & 8 & 9 \\
\hline \multicolumn{9}{|c|}{ Anthribidae } \\
\hline Anthribus nebulosus Forster, 1770 & $\mathrm{drb} / \mathrm{fst}$ & mzf/plp & 0.09 & - & - & 1 & - & - \\
\hline Dissoleucas niveirostris (Fabricius, 1798) & $\mathrm{drb} / \mathrm{fst}$ & $\mathrm{mzf} / \mathrm{plp}$ & 0.19 & 1 & 2 & - & - & - \\
\hline \multicolumn{9}{|c|}{ Brentidae } \\
\hline Apion rubiginosum Grill, 1893 & hrb/fst & $\mathrm{mzh} / \mathrm{mnp}$ & 0.03 & - & - & - & 1 & - \\
\hline Cyanapion columbinum (Germar, 1817) & $\mathrm{hrb} / \mathrm{mdw}$ & mzf/ olp & 0.03 & - & - & - & - & 1 \\
\hline Protapion apricans (Herbst, 1797) & $\mathrm{hrb} / \mathrm{mdw}$ & mzf/ olp & 0.06 & - & 1 & - & - & 1 \\
\hline Stenopterapion meliloti (W. Kirby, 1808) & $\mathrm{hrb} / \mathrm{mdw}$ & $\mathrm{mzf} / \mathrm{olp}$ & 0.03 & - & - & - & - & 1 \\
\hline \multicolumn{9}{|c|}{ Curculionidae } \\
\hline Anthonomus rectirostris (Linnaeus, 1758) & $\mathrm{drb} / \mathrm{fst}$ & mzf/ olp & 0.03 & - & - & 1 & - & - \\
\hline Attactagenus albinus (Boheman, 1833) & $\mathrm{hrb} / \mathrm{mdw}$ & $\mathrm{mzx} / \mathrm{plp}$ & 0.06 & - & 1 & - & - & - \\
\hline Aulacobaris lepidii (Germar, 1824) & $\mathrm{hrb} / \mathrm{mdw}$ & mzf/ olp & 0.09 & 1 & 1 & - & - & - \\
\hline Baris artemisiae (Panzer, 1794)* & hrb/ eut & mzf/ olp & 0.12 & - & - & - & 1 & 1 \\
\hline Bradybatus kellneri Bach, $1854^{\star}$ & $\mathrm{drb} / \mathrm{fst}$ & mzf/ olp & 0.45 & - & 1 & 2 & 2 & - \\
\hline Ceutorhynchus erysimi (Fabricius, 1787) & hrb/ eut & mzf/ olp & 0.06 & - & - & 1 & 1 & - \\
\hline Curculio glandium Marsham, $1802^{*}$ & $\mathrm{drb} / \mathrm{fst}$ & mzf/ olp & 0.19 & - & - & 1 & 1 & - \\
\hline Curculio rubidus (Gyllenhal, 1836)** & $\mathrm{drb} / \mathrm{fst}$ & mzf/ plp & 0.06 & - & - & 1 & 1 & - \\
\hline Cyphocleonus dealbatus (Gmelin, 1790) & sthb/ eut & $\mathrm{mzx} / \mathrm{olp}$ & 0.03 & - & - & - & 1 & - \\
\hline Dorytomus schoenherri Faust, $1883^{*}$ & $\mathrm{drb} / \mathrm{ltr}$ & $\mathrm{mzh} / \mathrm{mnp}$ & 0.03 & - & - & - & 1 & - \\
\hline
\end{tabular}


Continuation of Table 1

D. suratus (Gyllenhal, 1835)
D. longimanus (Forster, 1771)
Exomias pellucidus (Boheman, 1834)
Foucartia squamulata (Herbst, 1795)

Foucartia squamulata (Herbst, 1795)
Glocianus punctiger (C.Sahlberg, 1835)

Hexarthrum exiguum (Boheman, 1838)*

Hypera postica (Gyllenhal, 1813)

H. transsylvanica (Petri, 1901)

Ips sexdentatus Börner, 1767

Larinus turbinatus Gyllenhal, 1835

Liophloeus tessulatus (Müller, 1776)

Lixus subtilis Boheman, 1835

Mecaspis alternans (Herbst, 1795)

Melicius cylindrus (Boheman, 1838)*

Nedyus quadrimaculatus (Linnaeus, 1758)

Orchestes alni (Linnaeus, 1758)*

O. hortorum (Fabricius, 1792)*

Otiorhynchus albidus Stierlin, 1861 ${ }^{\star *}$

O. brunneus Krynicki, 1834

O. fullo (Schrank, 1781)

O. ovatus (Linnaeus, 1758)

O. raucus (Fabricius, 1777)

O. smreczynskii Cmoluch, 1968

O. velutinus Germar, 1824

Polydrusus inustus Germar, 1824

Pseudocleonus cinereus (Schrank, 1781)

Sciaphobus squalidus (Gyllenhal, 1834)

Scolytus mali Bechstein, 1805

Sitona callosus Gyllenhal, 1834

S. hispidulus (Fabricius, 1777)

S. humeralis Stephens, 1831

S. inops Gyllenhal, 1832

S. waterhousei Walton, 1846

Sitophilus granarius (Linnaeus, 1758)

S. oryzae (Linnaeus, 1763)

Sphenophorus striatopunctatus (Goeze, 1777)

Trachodes hispidus (Linnaeus, 1758)

Trachyphloeus alternans Gyllenhal, 1834

T. parallelus Seidlitz, 1868

Tropiphorus micans Boheman, $1842^{\star *}$

Tychius medicaginis C. Brisout, 1863

Urometopus nemorum L. Arnoldi, 1965
S. longulus Gyllenhal, 1834

\begin{tabular}{|c|c|c|c|c|c|c|c|}
\hline $\mathrm{drb} / \mathrm{ltr}$ & $\mathrm{mzh} / \mathrm{olp}$ & 0.03 & - & - & - & 1 & \\
\hline drb/ltr & mzf/ olp & 0.70 & - & - & - & 3 & 1 \\
\hline stgb/ eut & mzf/plp & 62.17 & 4 & 4 & 4 & 4 & 4 \\
\hline $\mathrm{hrb} / \mathrm{mdw}$ & mzf/plp & 0.03 & - & 1 & - & - & - \\
\hline $\mathrm{hrb} / \mathrm{mdw}$ & mzf/ olp & 0.26 & - & - & - & - & 2 \\
\hline $\mathrm{drb} / \mathrm{fst}$ & mzf/ plp & 0.03 & - & - & - & - & 1 \\
\hline sthb/ mdw & mzf/ olp & 0.06 & - & 1 & - & - & - \\
\hline sthb/ mdw & mzf/ olp & 0.03 & - & 1 & - & - & - \\
\hline $\mathrm{drb} / \mathrm{fst}$ & mzf/plp & 0.06 & - & - & - & - & 1 \\
\hline $\mathrm{hrb} / \mathrm{mdw}$ & mzf/ olp & 0.06 & - & - & 1 & 1 & - \\
\hline sthb/ eut & $\mathrm{mzh} / \mathrm{plp}$ & 0.12 & 1 & - & 1 & 1 & - \\
\hline hrb/ eut & $\mathrm{mzx} / \mathrm{olp}$ & 0.09 & - & - & - & 1 & 1 \\
\hline stg/ eut & $\mathrm{mzx} / \mathrm{olp}$ & 0.03 & - & - & - & - & 1 \\
\hline $\mathrm{drb} / \mathrm{fst}$ & mzf/plp & 0.03 & - & - & - & - & 1 \\
\hline hrb/ eut & $\mathrm{mzf} / \mathrm{mnp}$ & 0.06 & - & 1 & - & - & 1 \\
\hline $\mathrm{drb} / \mathrm{fst}$ & mzf/ olp & 0.06 & - & - & 1 & 1 & - \\
\hline $\mathrm{drb} / \mathrm{fst}$ & mzf/ olp & 0.03 & 1 & - & - & - & - \\
\hline stdb/ fst & $\mathbf{m z x} / \mathrm{plp}$ & 0.55 & - & - & 2 & 2 & 1 \\
\hline stgb/stp & mzx/ plp & 1.46 & - & - & 3 & 3 & - \\
\hline stdb/ fst & mzf/ plp & 0.77 & 2 & - & 3 & 2 & - \\
\hline stgb/ eut & mzf/ plp & 14.74 & - & 1 & 1 & 4 & 1 \\
\hline stgb/ eut & mzf/plp & 12.30 & 3 & 3 & 4 & 4 & 4 \\
\hline stdb/ fst & mzf/plp & 0.16 & - & - & 1 & 1 & 1 \\
\hline stgb/ stp & mzx/ plp & 0.98 & - & 3 & 1 & 1 & - \\
\hline stdb/ eut & mzf/plp & 0.12 & - & - & - & 1 & 1 \\
\hline sthb/ mdw & $\mathrm{mzx} / \mathrm{olp}$ & 0.12 & - & - & - & 1 & 2 \\
\hline drb/ fst & mzf/ plp & 1.58 & - & 1 & 3 & 2 & 3 \\
\hline $\mathrm{drb} /$ fst & mzf/ olp & 0.09 & - & - & - & - & 1 \\
\hline sthb/ mdw & mzf/ olp & 0.03 & - & - & - & 1 & - \\
\hline sthb/ mdw & mzf/ olp & 0.09 & - & - & - & 1 & - \\
\hline sthb/ mdw & mzf/ olp & 0.09 & - & 1 & - & 2 & - \\
\hline sthb/ mdw & mzf/ olp & 0.35 & - & 2 & - & 2 & - \\
\hline sthb/ mdw & mzf/ olp & 0.03 & - & - & - & 1 & - \\
\hline sthb/ mdw & mzf/ olp & 0.03 & - & - & - & 1 & - \\
\hline snt/ eut & mzf/ olp & 0.06 & - & - & - & - & 1 \\
\hline snt/ eut & mzf/ olp & 0.06 & - & - & - & - & 1 \\
\hline $\mathrm{stgb} / \mathrm{mdw}$ & mzf/ olp & 0.16 & - & - & - & 1 & 2 \\
\hline $\mathrm{drb} / \mathrm{fst}$ & $\mathrm{mzh} / \mathrm{plp}$ & 0.03 & 1 & - & - & - & - \\
\hline stg/ mdw & mzf/plp & 0.03 & - & 1 & - & - & - \\
\hline stg/ mdw & mzf/ plp & 0.16 & - & 2 & - & - & - \\
\hline stgb/ fst & $\mathrm{mzh} / \mathrm{plp}$ & 0.12 & 2 & - & - & - & \\
\hline $\mathrm{hrb} / \mathrm{mdw}$ & mzf/ olp & 0.03 & - & - & - & - & 1 \\
\hline stg/ eut & $\mathrm{mzh} / \mathrm{plp}$ & 0.48 & 1 & 1 & - & 3 & - \\
\hline
\end{tabular}

Notes. Habitat layers (vertical distribution): drb - dendrobionts; hrb - chortobionts; stg stratobionts; stgb - stratogeobionts; sthb - stratochortobionts; stdb - stratodendrobionts; snt — synanthropic. Habitat (biotopic) preference: fst - forest; mdw - meadow; stp - steppe; ltr - littoral; eut - eurytopic. Hygropreference (humidity): mzh - mesohygrophilous; mzf - mesophilous; mzx - mesoxerophilous. Trophic guilds (specialization): mnp - monophagous; olp - oligophagous; plp — polyphagous (omnivorous). By abundance: 4 - eudominant; 3 - subdominant; 2 - rare; 1 - single species; ${ }^{*}$ pecies was not indicated for Ukraine in the Catalogue of Palearctic Coleoptera (Catalogue..., 2011, 2013; Alonso-Zarazaga et al., 2017); ${ }^{* *}$ species was noted in Ukrainian left-bank Forest Steppe at first time; ${ }^{* * *}$ species was not indicated for Ukraine in the new edition of Catalogue of Palearctic Coleoptera (Alonso-Zarazaga et al., 2017); abundant species (eudominants and subdominants) are in bold. 
exiguum, Melicius cylindrus, Pseudocleonus cinereus, Tychius parallelus, T. medicaginis) are confirmed recent findings for Kharkiv Region (Yunakov et al., 2018).

It is difficult to compare the total taxonomic Curculinoidea composition of stratobios of the urban habitats of Kharkiv with those of other cities, due to the lack of similar data. Most of the publications available cover the entire complex of Curculionoidea, and not only stratobios habitat, and therefore, the number of species of the superfamily in some cities turned out to be 2-3 times higher than in the stratobios of Kharkiv urban habitats. But only 12-27 species were common for these cities (Ioannisiani, 1972; Matusevicz, 1991; Matusevicz, Kostin, 1994; Meleshko, Basanetz, 2001; Meleshko, 2002; Halinouski, 2005; Halinouski, Shauro, 2007; Petrenko, Nazarenko, 2007). This testifies both to the specificity of the weevils fauna of Kharkiv's urban habitats, and its insufficient knowledge. Taking into account these data, the general list of Curculionoidea of Kharkiv (not only in stratobios, but also in other habitats) can increase minimally to 140 species.

In quantitative terms (according to pitfall traps), the average proportion of Curculionoidea was $31.5 \%$, but, depending on the habitat, ranged from 10 to $74 \%$. On sampling plots weevils were accounted for about $30-40 \%$ of the total recorded Coleoptera. It means the number of weevils of stratobios in general was inferior to that of ground beetles and rove beetles, but in certain urban habitats Curculionoidea dynamic density was higher than other beetles (Komaromi et al., 2018). Only near 10 species are abundant (more than $97 \%$ of the abundance of Curculionoidea recorded) and two or three eudominants were registered in several plots (table 1). Nine species are considered rare, and more than 40 are registered as random elements.

Based on a representative analysis (Müller, 1980; Klausnitzer, 1990) of the distribution, eudominants Exomias pellucidus and Otiorhynchus raucus are attributed to transgradients (dominated in all plots of city), and O. ovatus - to exclusive elements (essentially dominated in one urban cenosis). Syndominant species are represented mainly by proximal D. longimanus, O. velutinus (prevailed in one of the plots) and dispersed elements (common in several urban areas) - O. albidus, O. brunneus, O. fullo and Sciaphobus squalidus.

Analysis of the main indices of species diversity showed their very low significance, indicating a high oligodominance of weevils in all urban areas. So, the Shannon index, depending on the year or area, ranged from $0.485-0.930$ to $1.326-1.820$, and the degree of equalization of Pielou, respectively, 0.124-0.500 (table 2). A similar trend has been noted in the indices of the

Table 2. Biodiversity indicators of Curculionoidea registered in the stratobios of urbocenosis of Kharkiv

\begin{tabular}{|c|c|c|c|c|c|}
\hline \multirow[b]{2}{*}{ Biodiversity indicators } & \multicolumn{5}{|c|}{ Urbanocenosis (data of $2017 / 2018$ ) } \\
\hline & Lisopark & $\begin{array}{l}\text { Parks of } \\
\text { city }\end{array}$ & $\begin{array}{l}\text { Plantings } \\
\text { of center }\end{array}$ & $\begin{array}{l}\text { Plantings of } \\
\text { periphery }\end{array}$ & $\begin{array}{l}\text { Household } \\
\text { plots of } \\
\text { city }\end{array}$ \\
\hline Total species / main species & $10 / 2$ & $19 / 3$ & $18 / 5$ & $33 / 6$ & $25 / 3$ \\
\hline Total genera & 9 & 14 & 11 & 17 & 20 \\
\hline Margalef index $\left(D_{M g}\right)$ & $\begin{array}{l}1.003 / \\
2.048\end{array}$ & $\begin{array}{l}3.022 / \\
2.289\end{array}$ & $\begin{array}{l}1.865 / \\
1.052\end{array}$ & $\begin{array}{l}1.541 / \\
3.094\end{array}$ & 3.63 \\
\hline Shannon index $\left(H^{\prime}\right)$ & $\begin{array}{c}0.9154 / \\
0.8073\end{array}$ & $\begin{array}{l}1.822 / \\
1.316\end{array}$ & $\begin{array}{c}0.5518 / \\
0.4848\end{array}$ & $\begin{array}{c}0.9302 / \\
1.448\end{array}$ & 1.584 \\
\hline Pielou index $(C)$ & $\begin{array}{c}0.4996 / \\
0.2242\end{array}$ & $\begin{array}{c}0.4759 / \\
0.3728\end{array}$ & $\begin{array}{c}0.1240 / \\
0.2030\end{array}$ & $\begin{array}{c}0.2535 / \\
0.2240\end{array}$ & 0.2321 \\
\hline Berger-Parker index $(D)$ & $\begin{array}{c}0.5556 / \\
0.8272\end{array}$ & $\begin{array}{c}0.4906 / \\
0.6667\end{array}$ & $\begin{array}{c}0.8692 / \\
0.8773\end{array}$ & $\begin{array}{l}0.7035 / \\
0.6339 /\end{array}$ & 0.502 \\
\hline $\begin{array}{l}\text { The proportion }(\%) \text { of Curculionoidea at } \\
\text { the total number of Coleoptera in the urban } \\
\text { cenoses }\end{array}$ & $\begin{array}{l}1.40 / \\
0.16\end{array}$ & $\begin{array}{c}10.4 / \\
0.11\end{array}$ & $\begin{array}{l}74.21 \\
7.92\end{array}$ & $\begin{array}{l}29.3 / \\
18.11\end{array}$ & 10.37 \\
\hline $\begin{array}{l}\text { The average density of Curculionoidea } \\
\text { at } 10 \text { pitfall trap-days per season }\end{array}$ & $\begin{array}{c}0.12 / \\
0.30\end{array}$ & $\begin{array}{c}0.20 / \\
0.24\end{array}$ & $\begin{array}{l}4.00 / \\
3.44 \\
\end{array}$ & $\begin{array}{c}0.94 / \\
1.56 \\
\end{array}$ & 1.15 \\
\hline
\end{tabular}

${ }^{\star}$ Data of 2018 only. 


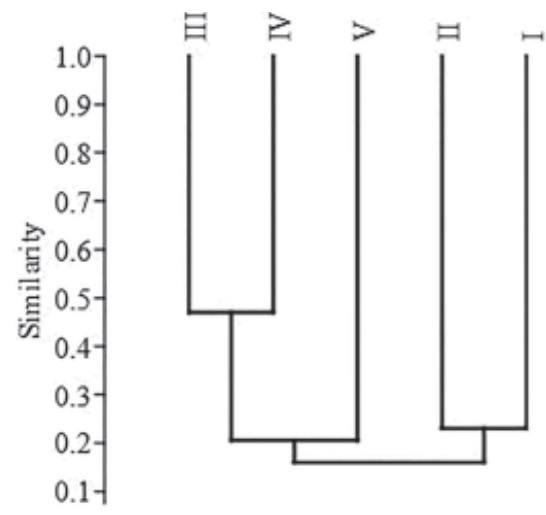

Fig. 1. The dendrogram of the similarities Curculinoidea in the urban areas of Kharkiv (data of 2017-2018): I — Lisopark; II — Parks of city; III - Plantings of center; IV - Plantings of periphery; V - Houseplant plots of the city.

species richness of Margalef and the dominance of Berger-Parker. At the same time, these indices are slightly higher in urban parks, plantings of suburbs, and in household plots, which indicates some (comparative) uniformity here of species diversity (table 2). They turned out to be minimal in the plantings of the center and in the Lisopark. The spectrum of species indices and the abundance of Curculionoidea are largely determined by the ecological and zonal timing of individual species. Based on the peculiarities of life, feeding habits and occurrence, all weevils registered in stratobios can be divided into several main ecological groups.

By habitat layers (vertical distribution) most Curculinoidea species are classified as chortobionts (herbaceous species inhabit on plants) and dendrobionts (inhabit on trees or shrubs). These groups are presented by 14 and 16 species respectively, but all of them are registered as random (27) or rare (4) elements. Only dendrobionts D. longimanus and S. squalidus is sporadically marked as common species (fig. 1). Weevil groups, to one degree or another closely related to stratobios, represented by 26 species and among them almost all abundant species are registered (including subdominants). Stratogeobionts ( 7 species, five abundant) and stratochortobionts (11 species) predominated quantitatively. The remaining groups were represented by few or single specimens (fig. 1, table. 1).

According to the biotopic preferences, meadow (21), forest and eurytopic (14) species are predominated qualitatively and quantitatively (table 1, fig. 2). Many forest species (except $O$. fullo and $S$. squalidus that sporadically register as ordinary elements) mainly represented by single individuals. Three eurytopic species dominated quantitatively (more than $90 \%$ of the total superfamily population) (table 1, fig. 2). At the same time, E. pellucidus as eudominant was assigned also to this group, although it was more often considered a forest representative (Yunakov et al., 2018). This species prevailed in all urban areas, but it was more common in sparse, almost open plantings (squares and lawns) of the center, outskirts of the city, and in household plots. In parks and suburban forests, its numbers declined tenfold (although it remained the dominant element). Representatives of other biotopic groups are recorded mainly as occasional and rare species. The exception was littoral $D$. longimanus, and steppe - O. brunneus, O. velutinus, sometimes recorded as common (table 1).

By hygropreference the typical mesophilous species were dominants, including most of the background elements ( 45 species, almost $98 \%$ of abundance all Curculinoidea). Mesoxerophilous and mesohygrophilous are represented by nine and five species, respectively, of which three are

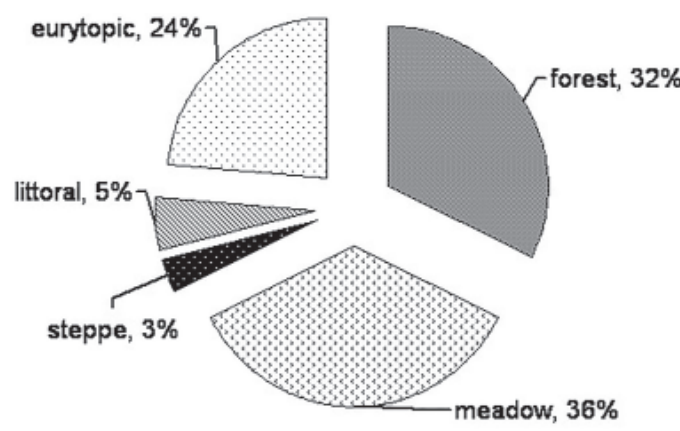

Fig. 2. The ratio (number of species, \%) of weevils by the habitat (biotopic) preferences in stratobios of the urban areas of Kharkiv. sometimes noted as subdominants (table 1).

According to trophic specialization, three groups were distinguished, of which oligophagous (32) and polyphagous (24 species) were dominant. Polyphagous (omnivorous) species (more than $95 \%$ of the number of the superfamily) prevailed quantitatively (due to background elements), while the total proportion of oligophagous did not exceed $4 \%$. All monophagous species are single.

The characteristics of the taxonomic and ecological structures also determine 
the differences in the qualitative and quantitative peculiarities of Curculionoidea for individual urban zones. The greatest number of species (25-33) was recorded in the plantings of the outskirts of the city and household plots (tables 1,2), and the dynamic density of beetles reached 1.50 individuals per 10 trap-days per season. On the territories of urban parks and plantings of the center, the number of species turned out to be slightly lower (18-19), but the density of weevils turned out to be maximum in the center (up to 4.00 ) and very low in parks $(0.20-0.24$ individuals per 10 trap-days per season). Minimum indicators were recorded in the

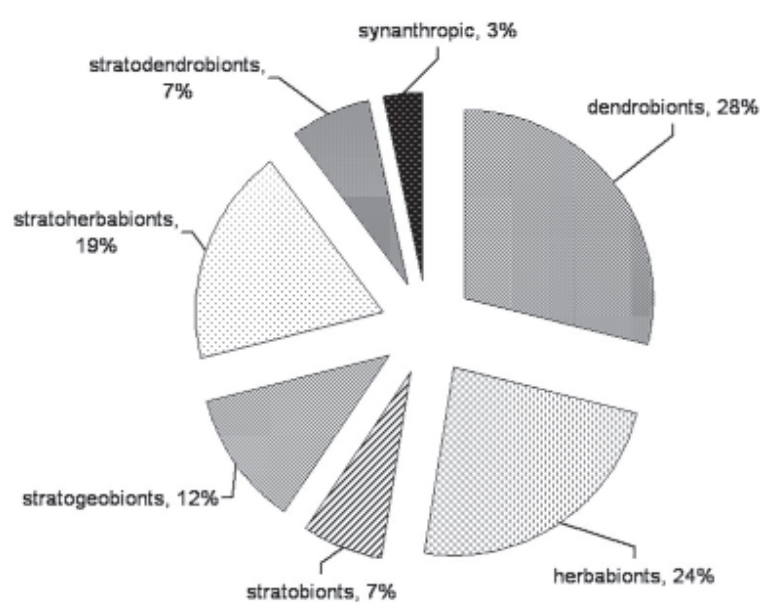

Fig. 3. The ratio (number of species, \%) of weevils by habitat layers (vertical distribution) in stratobios of the urban areas of Kharkiv.

Lisopark (10 species and 0.12-0.20 individuals per 10 trap days per season).

The spectrum of ecological groups turned out to be minimal in the Lisopark, but maximal in the vegetation of outskirts of the city and household plots (table 1,2). In terms of vertical distribution, the dendro-, chorto- and stratogeobionts; on biotopic preference forest, meadow and eurytopic elements; in terms of trophism, the oligo- and polyphagouses occur in all urban cenosis (fig. 1, 2; table 1). According to hygropreference, mesophilous dominated everywhere. In percentage terms, the share of different groups in individual urban habitats was not much different from the total indicator in the city at whole (see above). Thus, the main (conditional) representative of Curculionoidea in the stratobios can be considered as a eurytopic stratogeobiont mesophilous polyphagous species, i. e. it is an ecologically plastic species well adapted to living in the conditions of a city.

Differences in the qualitative and quantitative indicators of Curculionoidea in the areas identified significant differences in their faunal similarities (fig. 3). So, the Jacquard index ranged from 0.10 to 0.47 . The least similarity was observed between the Lisopark and the plantings of the center and periphery $(0.12-0.15)$, but especially with the household plots (0.09). Only when comparing forest areas with urban parks, the Jacquard ratio was close to the average (0.23). Almost the same values $(0.16-0.20)$ were observed when comparing the weevil's fauna of household plots with plantings of center and margins or the last two plots with urban parks. The maximum similarity indicators were observed when comparing Curculionoidea plantings of the center and outskirts of the city (0.47). The average value of the variation of the Jacquard index of $21.5 \%$ (i. e., exceeding $33 \%$ ) may indicate significant differences (i. e., faunistic specificity) in the composition weevils of the stratobios of different urban habitats of Kharkiv.

A number of reasons can explain the differences of qualitative and quantitative characteristics of Curculinoidea in different habitats. The main types of vegetation of the outskirts and center of the city are represented respectively by the territory of the botanical garden of Kharkiv National Pedagogical University with adjacent lands and a botanical natural plot "Institutsky" anthropogenic pressure in which is relatively insignificant. Generally such sites are a kind of refugia to many species of insects in the conditions of the city. This applies to household plots (cottages) in part.

At the same time, in most urban parks there are a significant recreational load (mainly trampling and destruction of grassy vegetation). This leads to significant soil compaction and the destruction of herbaceous vegetation in certain plots of the parks. Such factors are very negative for the existence and development of many insects, including weevils. The 
analysis of species diversity in the Lisopark indirectly confirm this. Plots with dense trees stands represent its main territory with much depleted grass cover and very compacted soil. Most weevils avoid habitats with such conditions, which was confirmed by the low abundance and depleted species composition of the superfamily.

\section{Conclusions}

The weevils (Curculionoidea) in the stratobios of the urban areas of Kharkiv, despite their considerable quantitative oligodominance, are characterized by rather rich species diversity. In total, 59 species from 41 genera and three families were registered. In quantitative terms, their average share was $31.5 \%$, but depending on the area, it ranged from 10 to $74 \%$. Near ten species are ranked as numerous and common, of which (depending on the site) 2-3 species are eudominants. Nine species are ranked as rare, and more than 40 as random elements. Four species of Curculionoidea (C. columbinum, C. rubidus, O. albidus, T. micans) are recorded for the first time in the FS. The analysis of faunistic diversity using the main indices showed their low value indicating a dominance of certain species of Curculionoidea.

By vertical distribution of imago, most species are classified as chortobionts and dendrobionts (14 and 16 species respectively), but almost all of them are recorded as occasional (30) elements in pitfall traps. The weevil groups associated with stratobios are represented by 26 species, among which most of the background elements are recorded. By biotope preference, meadow (21), forest and eurytopic (14) species are dominated. By trophic specialization, oligophagous (32) and polyphagous (24) species are numerous. In relation to humidity, the mesophilous species prevailed, among them the majority of abundant elements were noted (45 species). Thus, the number of eurytopic stratogeobiont mesophilous polyphagous species was maximal.

The largest number of species was recorded in vegetation of the outskirts of the city and household plots ( 25 and 33 species respectively), less in urban parks and vegetation of the center (18-19). The density of weevils in these urban habitats ranged from 0.20 to 4.00 specimen in 10 trap-days per season. The spectrum of ecological groups turned out to be minimal in the Lisopark, but the maximal in the vegetation of the suburbs and in the household plots. The average value of the similarity index was slightly more than 0.20 , indicating significant dissimilarity of the weevils species compositions of stratobios in different urban habitats of Kharkiv. Such differences are linked to variety of conditions in the urban zone (vegetation, soil type and physical properties, the nature of the anthropogenic pressure, humidity), which determine the ecological structure of Curculionoidea.

\section{References}

Aleksandrowicz, O., Krzętowski, B. 2004. Zgrupowania epigeicznych chrząszczy (Insecta: Coleoptera) na skarpie Łyny w Olsztynie. Fauna miast Europy Środkowej 21 wieku, Bydgoszcz: "Logo", 213-224 [In Polish].

Alonso-Zarazaga, M. A., Barrios, H., Borovec, R., Bouchard, P., Caldara, R., Colonnelli, E., Gultekin, L., Hlava, P., Korotyaev, B., Lyal, C. H. C., Machado, A., Meregalli, M., Pierotti, H., Ren, L., Sanchez-Ruiz, M., Sforzi, A., Silfverberg, H., Skuhrovec, J., Tryzna, M., Velazquez de Castro, A. J., Yunakov, N. N. 2017. Cooperative Catalogue of Palaearctic Coleoptera Curculionoidea. Monografias electronicas S.E.A., 8, 1-729.

Arnoldi, K. V., Arnoldi, L.V. 1963. About biocenosis as one of the basic concepts of ecology, its structure and content. Zoological journal, 42 (2), 161-183 [In Russian].

Belke, G. 1858. Krótki rys Historyi Naturalnéj Kamieńca Podolskiego. Stawowate (Articulata). Biblioteka Warszawska. Pismo poświęcone naukom, sztukom, i przemysłowi, 3, 361-362.

Belke, G. 1859. Rys historyi naturalnéj Kamieńca Podolskiego, poprzedzony krótką wiadomością of pracach uczonych w przedmiotach geologii, paleontologii, botaniki i zoologii, w Polsce w XIX wieku. Warszawa, 1-114.

Belke, G. 1866. Notice sur l'histoire naturelle du district Radomysl (Gouvernement de Kief). Bulletin de la Société impériale des naturalistes de Moscou, 39 (2), 491-526.

Brygadyrenko, V. V., Kabar, A. N. 2002. Ground beetles (Coleoptera, Carabidae) as a component of the herpetobios of the Botanical Garden of Dnepropetrovsk National University. Questions of steppe forest sciences and forest recultivation of the lands. DNU, Dnepropetrovsk, 6, 134-140 [In Russian]. 
Catalogue of Palearctic Coleoptera, 2011. Vol. 7. Curculinoidea. Löbl, I. I. \& Smetana, A., eds. Apollo Books, $1-373$.

Catalogue of Palearctic Coleoptera, 2013. Vol. 8. Curculinoidea II. Löbl, I. I. \& Smetana, A., eds. Apollo Books, $1-700$.

Cherkunov, N. 1889. Spisok zhukov, vodiashchikhsia v Kieve i ego okrestnostiakh. Zapiski Kievskogo Obshchestva Estestvoispytatelei, 10, 147-204. [1888, In Russian]

Cholewicka, K. 1981. Curculionids (Coleoptera, Curculionidae) of Wazsaw and Mazovia. Memorabilia Zoologica, 34, 235-258.

Chumakov, L. S. 1999. Influence of industrial emissions on weevil beetles (Coleoptera, Curculionidae) of perennial grasses. News of NAS of Belarus, Seria Biological Sciences, 4, 94-97 [In Russian].

Cmoluch, Z. 1972. Weevils (Coleoptera, Curculionidae) of town plants associations of Lubhn. Polskie Pismo Entomologiczne, 42, 545-562.

Elechtner, G., Klinger, R. 1991. Zur Insektenfauna einer Grossstagt: Käferfunde aus Frankfurt-Main. Mitteilungen des Internationalen Entomologischen Vereins, Frankfurt am Main, 16 (1-2), 37-82.

Fedyay, I. A., Markina, T. Yu., \& Putchkov, A. V. 2018. Ecological and faunistic survey of the true bugs of the infraorder Pentatomomorpha (Hemiptera) in the urban cenosis of Kharkiv City (Ukraine). Biosystems Diversity, 26 (4), 263-268. doi:10.15421/011840.

Folwaczny, B. 1973. Bestimmungstabelle der paläarktischen Cossoninae (Coleoptera, Curculionidae) ohne die nur in China und Japan vorkommenden Gattungen, nebst Angaben zur Verbreitung. Entomologische Blätter, 69, 65-180.

Franzen, B. 1992 a. Untersuchungen zur Käferfauna an ausgewählten Standorten in Köln (Insecta: Coleoptera). Decheniana, 150, 181-216.

Franzen, B. 1992 b. Vorläufige Liste der Käfer von Köln (Insecta: Coleoptera). Decheniana, 150, 217-249.

Gilyarov, M. S. 1987. Accounting for large invertebrates (mesofauna). In: Dunger et al., eds. Quantitative methods in soil zoology. Science, Moscow, 1-288.

Halinouski, N. G. 2005. Dynamics of seasonal activity of the herpetibio beetle Trachyphloeus bifoveolatus (Beck, 1817) in the conditions of Minsk city. Vestnik Belarusian State University, 2, Chemistry. Biology. Geography, 2, 47-50 [In Russian].

Halinouski, N. G., Shauro. 2007. Species composition and structure of herpetobiont beetles (Ectognatha, Coleoptera) of greenery in Minsk. Proceedings of the Belarusian State Technological University, Ser. I. Forestry, 15, 333-337 [In Russian].

Hormuzaki, C. von 1888. Beiträge zur Käferfauna der Bukovina und Nordrumaliens. Entomologische Nachrichten und Berichte, 14 (1-9), 21-31, 34-41, 67-77, 93-96, 105-110, 148-156, 161-169.

Ioannisiani, T. G. 1972. The weevil beetles (Coleoptera, Curculionidae) of Belarus. Navuka and Technika, Minsk, 1-352 [In Russian].

Kirichenko, M. B., Danylkiv, J. M. 2011. The species diversity of beetles (Coleoptera, Cicindelidae, Carabidae) on the protected areas in the city of Kyiv. Vestnik Zoologii, 45 (5), 411-420 [In Ukrainian].

Klausnitzer, B. 1983. Faunistisch-Ökologische Untersuchungen über die Laufkäfer (Coleoptera, Carabidae) des Stadtgebietes von Leipzig. Entomologische Nachrichten und Berichte, 27, 241-261.

Klausnitzer, B. 1990. Ecology of the urban fauna. Mir, Moscow, 1-248 [In Russian].

Komaromi, N. A., Nikolenko, N. Yu., Puchkov, A. V. 2018. The faunistic structure of the beetles (Insecta: Coleoptera) in herpetobios of urbocenosis of Kharkov. Ukrainian entomological journal. 2 (15), 3-21. doi: 15421/281809 [In Russian].

Komaromi, N. A., Puchkov, A. V., Nazarenko V. Yu. 2019. Peculiarities of Seasonal Changes of Taxonomic Structure And Number of Weevil-Beetles (Coleoptera, Curculionidae) of Herptobios In Kharkiv Urbocenoses (Ukraine). Ukrainian entomological journal. 1 (16). 25-35. doi: .15421/281905"https://doi.org/ HYPERLINK “https://doi.org/10.15421/281905”10HYPERLINK “https://doi.org/10.15421/281905”. HYPERLINK “https://doi.org/10.15421/281905”15421HYPERLINK “https://doi.org/10.15421/281905”/ HYPERLINK “https://doi.org/10.15421/281905”281905 [In Russian].

Korotyaev, B. A., Kataev, B. V. Kovalev A. V. 2018. On records of three additional species of the weevil genus Otiorhynchus Germ. (Coleoptera, Curculionidae: Entiminae) on lilacs (Syringa L.) in St. Petersburg. Entomologicheskoye obozreniye, 97 (1), 93-101. doi: 10.1134/S0013873818070126 [In Russian].

Korotyaev, B. A., Kataev, B. V. Kovalev A. V. 2019. On the persistence of populations of three invasive species of the weevil genus Otiorhynchus Germ. (Coleoptera, Curculionidae: Entiminae) on lilacs (Syringa L.) in St. Petersburg in 2018. Entomologicheskoye obozreniye, 98 (1), 184-185. doi: 10.1134/S0367144519010179 [In Russian].

Krynicki, I. 1832. Enumeratio Coleopterorum Rossiae meridionalis et praecipe in Universitatis Caesareae Charkoviensis circulo ovbenientium, quae annorum 1827-1831 spatio observavit. Bulletin se la Société Imperiale des Naturalistes de Moscou, 5, 65-179.

Lebedeva, N. V., Drozdov, N. N., Krivolutsky, D. A. 2004. Biological diversity and methods for its assessment. Humanity center VLADOS, Moscow, 1-432 [In Russian].

Łomnicki, A. M. 1874. Wykaz dodatkowy chrząszczów galicyjskich. Sprawozdanie Komisyi Fizyjograficznéj obejmijące poglą na czynności dokonane $w$ ciagu roku 1873, oraz materyjały do fizyjografii Galicyi, Kraków, 8, 12-18 
Łomnicki, A. M. 1884. Catalogus Coleopterorum Haliciae, Leopoli, 1-43.

Matusevicz, S. A. 1991. New species of weevils (Coleoptera, Curculionidae) in the fauna of BSSR. Fauna and ecology of beetles of Belorussia, Navuka and Tehnika, Minsk: 181-184 [In Russian].

Matusevicz, S. A. Kostin, E. E. 1994. Species diversity of weevil beetles (Coleoptera, Curculionidae) in the urbancenosis of Minsk. Problems of studying, preserving and using the biological diversity of the animal world: Mes. report VII Zoological Conference, Minsk, 133-135 [In Russian].

Meleshko, J. E. 2002. To the studying of the species composition of weevils (Coleoptera, Curculionidae) of Minsk city. Anthropogenic landscape dynamics and problems of conservation and sustainable use of biological diversity, Minsk, 169-170 [In Russian].

Meleshko, J. E., Basanrtz, S. L. 2001. Some features of the distribution of weevils on plants of Salix and Populus genera. In: Lopatin, I. K, ed. Diversity of the Animal World of Belarus: Results of the Study and Perspectives for Conservation Minsk, 112-115 [In Russian]..

Molodova, L. P. 1990. Structure of the herpetobiont beetle fauna in biotopes of Gomel. Bulletin of BSU. Ser.2. Chemistry. Biology. Geography, 3, 39-42 [In Russian].

Molodova, L. P. 1991. Quantitative and qualitative characteristics of herpetobiont beetles in the region of a large industrial association in Gomel Fauna and ecology of the beetles in Belarus. Science and Technology, Minsk, 185-192 [In Russian].

Müller, P. 1980. Anpassung und Informationsgehalt von Tierpopulationen in Städten. Verhandlungen der Deutschen Zoologischen Gesellschaft, Stuttgart, 57-77.

Nazarenko, V. Yu., Petrenko, A. A. 2007 (2008). To the knowledge of beetle fauna (Insecta: Coleoptera) of Lysa Gora (Kyiv). The Kharkov Entomological Society Gazette, 15 (1-2), 43-48 [In Ukrainian].

Nazarenko, V. Yu., Putchkov, A. V., Komaromi, N. A. 2018. Review of weevil beetles (Coleoptera, Curculionidae) in herpetobios of urbocenosis in Kharkiv. Abstracts of the 9th Congress of UES, Kharkiv, 85-86 [In Russian].

Nikolenko, N. Yu. 2018. Ecological and faunistic overeview of the carabidofauna (Coleoptera, Carabidae) in urbocenosis of Kharkiv. Biology and Valeology, 20, 48-54. doi.org/10.5281/zenodo.2543628 [In Ukranian].

Nowicki, M. 1858. Coleopterologisches über Ostgalizien. Jahres-Bericht der kaiserlichen und königlichen OberGymnasium zu Sambor für der Schuljahr, Wien, S. 1-16

Putchkov, A. V. 2018. Ground-beetles (Coleoptera, Carabidae) of transformed cenosis of Ukraine. Kiev, 1-448. doi: 10.15421/511802 [In n Russian].

Putchkov, A. V. Brygadyrenko, V. V. Markina, T. Y. 2019. Ground beetles of the tribe Carabini (Coleoptera, Carabidae) in the main megapolises of Ukraine. Vestnik zoologii, 53 (1), 3-12. doi 10.2478/vzoo-20190001.

Puchkov, A. V., Komaromi, N. A. 2018. The clown beetles (Coleoptera, Histeridae) of the urbocenosises of Kharkiv city (Ukraine). Biology and Valeology, 20, 54-58, doi.org/10.5281/zenodo.2543636 [In Russian].

Putchkov, A. V., Kyrychenko, M. B., Uspensky, G. B. 2003. Ground beetles (Coleoptera, Carabidae) of Lysa Hora tract in Kyiv. Vestnik Zoologii, 16, 111-113 [In Russian].

Putchkov, A. V., Markina, T. Yu. Komaromi, N. A. 2017 a. Ecologo-faunistic review of Lamellicorn Beetles (Coleoptera, Scarabaeoidea) of urbocenozis of Kharkov city (Ukraine). Biosystems Diversity, 25 (4), 263267. doi 10.15421/011740 [In Russian].

Putchkov, A. V., Markina, T. U., Skavysh, M. 2016. Preliminary selection of herpetobiont beetles (Coleoptera) of park plantings of Kharkiv (Ukraine). Ukrainian entomological journal, 11 (1-2), 69-76 [In Russian].

Putchkov, A. V., Nikolenko, N., Garkusha, I. A. 2017 b. Ecologic-faunistical overview on the ground beetles of Pterostichini (Coleoptera, Carabidae) tribe in park urbocenosis of Northern and Eastern Ukraine. Biology and Valeology, 19, 69-78. doi.org/10.5281/zenodo.1108520 [In Russian].

Rizun, V. B., Diedus, V. I. 2016. Ecologic-biological peculiarities of groups of ground beetles (Coleoptera, Carabidae) of Vynnykivsky urban forest of Lviv. Scientific notes of the State Natural History Museum, 32, 129-136 [In Ukrainian].

Rizun, V. B., Khrapov, D. S. 2001. On the study of ground beetles (Coleoptera, Carabidae) of Lviv (Sykhivsky and Vynnykivsky urban forests). Scientific notes of the State Natural History Museum of NAS of Ukraine, 16, 103-108 [In Ukrainian].

Skufyin, K. V. 1968. The structure of the at-soil (herpetobium) invertebrate inhabitants under conditions of forest-steppe landscapes of Voronezh region. Vestnik Zoologii, 2, 26-32 [In Russian].

Yakhontov, V. V. 1964. Ecology of insects. Moscow, 1-458 [In Russian].

Yunakov, N. Nazarenko, V., Filimonov, R., Volovnik, S. 2018. A survey of the weevils of Ukraine (Coleoptera: Curculionoidea). Zootaxa, 4404 (1), 1-494. doi.org/10.11646/zootaxa.4404.1.1

Weidner, H. 1983. Herkunft einiger in Mitteleuropa vorkommender Vorratsschädlinge: 1. die Sitophilus-Arten (Coleoptera, Curculionidae). Mitteilungen des Internationalen Entomologischen Vereins, Frankfurt am Main, 8, 1-17.

Received 28 August 2019

Accepted 25 February 2020 